\title{
Detection of Serum-Dependent Cytotoxic Activity of Campylobacter jejuni and its Characteristics
}

\author{
Naoaki MISAWA, Takahiro OHNISHI, Kikuji ITOH ${ }^{1)}$, and Eiji TAKAHASHI') \\ Department of Veterinary Public Health, Faculty of Agriculture, Miyazaki University, Gakuen-Kibanadai, Miyazaki 889-21 \\ and "Department of Veterinary Public Health, Faculty of Agriculture, The University of Tokyo, Bunkyo-ku, Tokyo 113, Japan
}

(Received 10 April 1995/Accepted 25 September 1995)

ABSTRACT. We previously set forth appropriate three assay systems using Chinese hamster ovary cells to detect the Campylobacter jejuni cytotoxin. Although we could not reach a conclusion because the cytotoxins shown in this study were not purified, at least three different cytotoxins were detected in these assay systems. The first cytotoxin detected in the presence of fetal calf serum (FCS) was heat-labile and the molecular weight $(\mathrm{Mw})$ was estimated at $50-100 \mathrm{k}$ by ultrafiltration. The second cytotoxin detected in the presence of newborn calf serum (NCS) was heat-stable and Mw was estimated at 0.5-3.0 k. The third cytotoxin detected in serum-free culture (SFC) assay was heat-labile and non dialyzable. However, Mw was not estimated since the low Mw and heat-stable cytotoxin was also detected in this assay. The cytotoxic activity detected in FCS and NCS assays, but not that detected in SFC assay, was completely abolished by treatment with a reducing agent. In contrast, the cytotoxicity detected in both FCS and NCS assays was not inactivated by such an enzyme as trypsin, lipase, neuraminidase, and $\beta$-galactosidase. When the filtrate was heated at $100^{\circ} \mathrm{C}$ to inactivate the heat-labile cytotoxin, the cytotoxic activity was detected in the NCS assay but not in FCS assay. However, when NCS was added to this heated filtrate, the cytotoxicity was restored in FCS assay. Furthermore, when normal rabbit serum (NRS) was added, no cytotoxicity was restored. The cytotoxic activity in SFC assay was completely inactivated with FCS or NRS. These findings suggest that the cytotoxic activity is dependent on serum added to tissue culture medium and that the substance amplifying and/or inhibiting the cytotoxic activity may be present in serum. - KEY wORDs: Campylobacter jejuni, characteristic, cytotoxin, serum, tissue culture.

J. Vet. Med. Sci. 58(2): 91-96, 1996

Campylobacter jejuni has been recognized as an important enteric pathogen throughout the world $[3,5,36]$ and great efforts have been made by many researchers to clarify the pathogenic mechanism with in vivo or in vitro models [37]. It is considered that the toxin produced by $C$. jejuni is one of the most important factors causing illness. Although the mechanism by which these toxins cause diarrhea is not clearly understood. C. jejuni is known to produce two types of toxins. One is a cytotonic enterotoxin $[2,6,7,10,16,20-22,26,27,34,35]$ which is immunologically related to both cholera toxin and heat-labile Escherichia coli enterotoxin, and the other is a cytotoxin [1, $8,9,11,13,23,25,28,30,31,38]$. Although many reports have been published on $C$. jejuni cytotoxin, it is difficult to determine whether the identical toxin was detected, because the procedures for its production and detection have differed among researchers. Furthermore, the cytotoxin was not produced in high concentrations and the characteristics were complicated by loss of the cytotoxic activity during purification by classical techniques [15]. Consequently, the results are conflicting. We previously reported that an appropriate assay system using tissue culture to detect the cytotoxin produced by $C$. jejuni had been developed, and the effect of culture conditions on cytotoxin production was examined [29]. The study demonstrated that the production and detection of cytotoxin was greatly influenced by the culture conditions and assay system employed. We developed three assay systems that use different tissue culture media for Chinese hamster ovary ( $\mathrm{CHO}$ ) cells, i.e., minimum essential medium (MEM) supplemented with $20 \%$ fetal calf serum (FCS) or 10\% newborn calf serum (NCS), and serum-free culture (SFC) medium. Furthermore, our results on the cytotoxin produced by the reference strains in the three assay systems did not agree with toxin production in the original reports. In this study, we attempted to characterize the crude cytotoxin in the culture filtrate of $C$. jejuni, and to determine whether the identical cytotoxin was detected in the three assay systems. We determined also the effect of serum on cytotoxic activity in each of the three assay systems.

\section{MATERIALS AND METHODS}

Bacterial strains: $C$. jejuni strain BL107 isolated from a necrotic lesion of chicken hepatitis was used in this study since this strain gave the highest titer of all strains tested in our laboratory. The strains were suspended in Nutrient Broth No. 2 (Oxoid Ltd., England) containing 10\% dimethylsulfoxide (Sigma Chemical Company, U.S.A.) and stored at $-80^{\circ} \mathrm{C}$ until tested.

Cytotoxin production: $C$. jejuni was grown on horse blood agar plates for $24 \mathrm{hr}$ at $42^{\circ} \mathrm{C}$ under a gas mixture containing $5 \% \mathrm{O}_{2}, 5 \% \mathrm{H}_{2}, 10 \% \mathrm{CO}_{2}$ and $80 \% \mathrm{~N}_{2}$. A loopful of bacteria was inoculated into $20 \mathrm{~m} l$ of Brucella broth (BBL Microbiology Systems, Cockeysville, MD) in a flask and the initial optical density at $550 \mathrm{~nm}$ was adjusted to 0.1 to 0.2 . The cultures were incubated at $42^{\circ} \mathrm{C}$ for 4 days stationarily or for 2 days with stirring (100 rpm). The final optical density after these culture conditions usually ranged from 1.0 to 1.5. The broth culture was centrifuged at 10,000 
$\times \mathrm{g}$ for $30 \mathrm{~min}$ at $4^{\circ} \mathrm{C}$ and filtered through a $0.20-\mu \mathrm{m}$ cellulose nitrate membrane (Advantec Toyo Ltd., Tokyo). The supernatant was stored at $4^{\circ} \mathrm{C}$ until testing. The sample was used for characterization within three days after the preparation of the culture filtrate.

Assay for cytotoxin: Cytotoxic activity was detected with three tissue culture assay systems developed previously [29]. In brief, trypsinized $\mathrm{CHO}$ cells (supplied by Japanese Cancer Resource Bank, Tokyo) were suspended in Eagle's minimum essential medium (MEM, Nissui Pharmaceutical Co., Tokyo) containing 20\% fetal calf serum (FCS, Flow Laboratories, Inc., McLean, VA) or 10\% newborn calf serum (NCS, Gibco Laboratories, Grand Island, NY), or ASF 104 medium (Ajinomoto Co., Ltd., Tokyo) as a serum-free culture (SFC). A volume of $100 \mu l$ containing $5 \times 10^{3}$ cells of cell suspensions was placed in each well of a 96-well microplate, and allowed to adhere to the bottom of the well for 1 to 3 $\mathrm{hr}$. Then $100 \mu \mathrm{l}$ of bacteria free supernate was added to each well, followed by incubation at $37^{\circ} \mathrm{C}$ for $72 \mathrm{hr}$ under $5 \% \mathrm{CO}_{2}$ in air. The wells showing rounding by more than $30 \%$ of the cells were considered positive. Brucella broth alone was used as a negative control. The cytotoxic titer was indicated as the reciprocal of the highest of twofold dilutions giving positive cytotoxicity.

Characteristics of the cytotoxic factors:

(1) Heat lability: Culture filtrates were heated for 30 min at $56,70,100$ (boiling) or $121^{\circ} \mathrm{C}$ (heating in an autoclave). After cooling, the cytotoxic effect on $\mathrm{CHO}$ cells was determined in the three assay systems.

(2) pH lability: Culture filtrate was adjusted by addition of $2 \mathrm{~N} \mathrm{HCl}$ or $2 \mathrm{~N} \mathrm{NaOH}$ to cover the $\mathrm{pH}$ range from 1 to 10 , and incubated at $37^{\circ} \mathrm{C}$ for $1 \mathrm{hr}$. After incubation, the overall $\mathrm{pH}$ was then re-adjusted to 7.0 and cytotoxin assay was performed.

(3) Molecular weight estimation: Molecular weights $(\mathrm{Mw})$ of cytotoxic factors were estimated by ultrafiltration and dialysis. Ultrafiltration of $20 \mathrm{~m} l$ of the filtrate was performed in an Amicon model 8050 (Amicon Inc., U.S.A.) unit fitted with a Diaflo ultrafilter consisting of YC05 (0.5 k cutoff), YM1 (1 k cutoff), YM3 (3 k cutoff), YM10 (10 k cutoff), YM30 (30 k cutoff), XM50 (50 k cutoff), YM100 (100 k cutoff) and XM300 (300 k cutoff). The filtrate through each membrane was assayed for the cytotoxic activity in the three assay systems. Dialysis was also undertaken with a cellulose tube (Spectra/Por ${ }^{\circledR} 1$; Serva Feinebiochemica GmbH \& Co., Germany) with a cutoff of 6 to $8 \mathrm{k}$. The filtrate was dialyzed for $24 \mathrm{hr}$ at $4^{\circ} \mathrm{C}$ with two changes of $10 \mathrm{mM}$ phosphate buffered saline (pH 7.2) and determined for the cytotoxic titer.

(4) Effects of enzymes and reducing agents: The filtrate was treated with $1 \mathrm{mg} / \mathrm{m} /$ of trypsin $(1: 250$, Difco Laboratories, Detroit, MI, U.S.A.), $1 \mathrm{U} / \mathrm{m} l$ of lipase (Sigma Chemical Co., St. Louis, MO), neuraminidase (Sigma) or $\beta$ galactosidase (Boehringer Mannheim GmbH, Mannheim, Germany). The filtrates were treated with $0.25 \mathrm{mg} / \mathrm{ml}$ of dithiothreitol (Nacalai Tesque Co., Tokyo), sodium metabisulfite (Nacalai Tesque), or L-cysteine monohydrochloride (Wako Pure Chemical Industries, Osaka) as a reducing agent. Each reagent was prepared at 20 -fold concentration as the final concentration. The mixture was incubated at $37^{\circ} \mathrm{C}$ for $1 \mathrm{hr}$, and the cytotoxic titer was compared with untreated filtrates.

(5) Effect of serum: Normal rabbit serum (NRS; Cosmobio Co., Ltd., Tokyo), FCS or NCS was added to the filtrate or the SFC assay system at $10 \%$, and the cytotoxicity was determined. The cytotoxic activity in the culture filtrate heated at $100^{\circ} \mathrm{C}$ for $30 \mathrm{~min}$ or dialyzed as described above before serum addition was determined.

(6) Immunological cross-reactions: The immunological cross-reactions were determined by reversed passive latex agglutination (RPLA), enzyme immunosorbent assay (ELISA) or the neutralization test. Bacteria-free culture filtrate was assayed for Vibrio cholerae toxin (CT)Escherichia coli heat-labile enterotoxin (LT) or E. coli Shiga-like toxins (SLT) I and II with RPLA kits (Denka Seiken Co., Ltd., Tokyo). The cross-reaction with E. coli heat-stable enterotoxin (ST) was determined with an ELISA assay kit (Denka Seiken). For the neutralization test, rabbit antiserum against $C$. jejuni heat-labile antigen of BL107 strain was prepared according to the method of Lior [24] for serotyping. The filtrate was incubated with antiserum at 1:20 for $1 \mathrm{hr}$ at $37^{\circ} \mathrm{C}$ before being added to the cells.

\section{RESULTS}

Heat lability: The cytotoxicity was completely inactivated in the FCS assay system at higher than $100^{\circ} \mathrm{C}$, but it was highly stable in the NCS assay even at $121^{\circ} \mathrm{C}$. The cytotoxic activity detected in the SFC assay was mostly heat-labile and partially heat-stable (Table 1).

pH lability: The $\mathrm{pH}$ lability of $C$. jejuni cytotoxin is show in Table 2. Although the cytotoxic activity in the FCS and SFC assay systems were completely lost at pH below 3.0, a low activity was detected in NCS assay.

Estimation of $M w$ : As shown in Table 3, the Mws of the cytotoxin detected in the three assay systems were different from one to another. The cytotoxin detected in the FCS assay was nondialyzable and estimated at 50 to $100 \mathrm{k}$. That detected in NCS assay was dialyzable and estimated at 0.5 to $3 \mathrm{k}$. In contrast, that detected in SFC assay was mostly nondialyzable but $\mathrm{Mw}$ was not necessarily uniform in

Table 1. Heat lability of $C$. jejuni cytotoxic effect on $\mathrm{CHO}$ cells

\begin{tabular}{cccc}
\hline \multirow{2}{*}{$\begin{array}{c}\text { Sample treated } \\
\left({ }^{\circ} \mathrm{C}\right)\end{array}$} & \multicolumn{3}{c}{ Cytotoxic titer } \\
\cline { 2 - 4 } & $\begin{array}{c}\text { FCS } \\
\text { assay }\end{array}$ & $\begin{array}{c}\text { NCS } \\
\text { assay }\end{array}$ & $\begin{array}{c}\text { SFC } \\
\text { assay }\end{array}$ \\
\hline unheated & 4 & 8 & 128 \\
56 & 2 & 8 & 128 \\
70 & 2 & 8 & 128 \\
100 & $<2$ & 8 & 16 \\
121 & $<2$ & 4 & 8 \\
\hline
\end{tabular}


ultrafiltration.

Effect of enzyme and reducing agents: The cytotoxic activity was hardly changed upon treatment with any of the enzymes used in this study in the FCS or NCS assay system (Table 4). However, the activity decreased by about $50 \%$ when the filtrate was treated with trypsin, but it was not judged as intact negative. The effect of enzyme in SFC assay could not be determined since the cytotoxicity was observed as positive even when an enzyme solution other than $\beta$-galactosidase was added to the cells as a negative control. Treatment of the filtrates with a reducing agent at $0.25 \mathrm{mg} / \mathrm{ml}$ completely abolished the cytotoxic activity in the FCS and NCS assay systems but not in the SFC assay.

Effect of serum: Addition of FCS, NCS or NRS to the filtrate did not affect the cytotoxic activity when $\mathrm{CHO}$ cells had already been cultivated with FCS or NCS. However, when the filtrate was dialyzed to remove low Mw cytotoxin, the cytotoxic activity was recovered with FCS added to the NCS assay system (Table 5). When the filtrate was heated at $100^{\circ} \mathrm{C}$ to inactivate heat-labile cytotoxin, the cytotoxic activity was restored by addition of NCS to FCS assay. In contrast, when NRS was added, no cytotoxicity was restored. Furthermore, when the filtrate was dialyzed and heated to

Table 2. Effect of pH on cytotxic activity

\begin{tabular}{cccc}
\hline \multirow{2}{*}{$\mathrm{pH}$ range } & \multicolumn{3}{c}{ Cytotoxic titer } \\
\cline { 2 - 4 } & $\begin{array}{c}\text { FCS } \\
\text { assay }\end{array}$ & $\begin{array}{c}\text { NCS } \\
\text { assay }\end{array}$ & $\begin{array}{c}\text { SFC } \\
\text { assay }\end{array}$ \\
\hline $1-2$ & $<2$ & 2 & $<2$ \\
$2-3$ & $<2$ & 2 & $<2$ \\
$3-4$ & 2 & 4 & 32 \\
$4-5$ & 4 & 8 & 64 \\
$5-6$ & 4 & 8 & 128 \\
$6-7$ & 4 & 8 & 128 \\
$7-8$ & 4 & 8 & 128 \\
$8-9$ & 4 & 8 & 128 \\
$9-10$ & 2 & 8 & 64 \\
Untreated & 4 & 8 & 128 \\
\hline
\end{tabular}

Table 3. Estimation of the molecular weight

\begin{tabular}{cccc}
\hline \multirow{2}{*}{$\begin{array}{c}\text { Mw cutoff } \\
(\mathrm{kDa})\end{array}$} & \multicolumn{3}{c}{ Cytotoxic titer } \\
\cline { 2 - 4 } & $\begin{array}{c}\text { FCS } \\
\text { assay }\end{array}$ & $\begin{array}{c}\text { NCS } \\
\text { assay }\end{array}$ & $\begin{array}{c}\text { SFC } \\
\text { assay }\end{array}$ \\
\hline 0.5 & $<2$ & $<2$ & $<2$ \\
1 & $<2$ & 2 & 16 \\
3 & $<2$ & 4 & 8 \\
10 & $<2$ & 4 & 8 \\
30 & $<2$ & 4 & 8 \\
50 & $<2$ & 4 & 32 \\
100 & 4 & 8 & 128 \\
300 & 4 & 8 & 128 \\
Dialysis $\left.{ }^{b}\right)$ & 2 & $<2$ & 64 \\
Untreated $^{2}$ & 4 & 8 & 128 \\
\hline
\end{tabular}

a) Cytotoxic titer of the culture filtrate passed through the ultrafiltration membrane is shown.

b) The culture filtrate was dialyzed for $24 \mathrm{hr}$. exclude both heat-labile and low Mw cytotoxins, the cytotoxic activity was not restored by addition of NCS to FCS assay nor by addition of FCS to NCS assay. The cytotoxic activity in SFC assay was completely depressed with FCS or NRS, and the titer reduced from 1:128 to 1:8 by addition of NCS (Table 6).

Immunological cross-reactions: No immunological crossreaction was detected between the epitopes of $C$. jejuni cytotoxins and CT, LT, SLT (I and II) or ST with the RPLA or ELISA assay kit. Reference toxins were detectable at 1$2 n \mathrm{~g} / \mathrm{m} l$ and 10 to $20 n \mathrm{~g} / \mathrm{m} l$ with the RPLA and ELISA kits, respectively. The cytotoxic activity was not neutralized with the antibody against heat-labile antigen in FCS or NCS assay systems. The neutralization test in SFC assay could not be performed since the antiserum, prepared from the rabbit abolished the cytotoxic activity in the SFC assay system using NRS.

Table 4. Effects of enzymes and reducing agents on the cytotoxic activity

\begin{tabular}{lccc}
\hline \multirow{2}{*}{ Sample treat with } & \multicolumn{3}{c}{ Cytotoxic titer } \\
\cline { 2 - 4 } & $\begin{array}{c}\text { FCS } \\
\text { assay }\end{array}$ & $\begin{array}{c}\text { NCS } \\
\text { assay }\end{array}$ & $\begin{array}{c}\text { SFC } \\
\text { assay }\end{array}$ \\
\hline Trypsin & 2 & 8 & ND \\
Lipase & 4 & 8 & ND \\
Neuraminidase & 4 & 8 & ND \\
B-galactosidase & 4 & 8 & 128 \\
Dithiothreitol & $<2$ & $<2$ & 128 \\
Sodium metabisulfite & $<2$ & $<2$ & 128 \\
L-cysteine & $<2$ & $<2$ & 128 \\
Untreated & 4 & 8 & 128 \\
\hline
\end{tabular}

a) Not determined.

Table 5. Effects of heating, dialysis and addition of serum on the cytotoxic activity in the FCS and NCS assay systems

\begin{tabular}{|c|c|c|c|}
\hline \multirow{2}{*}{\multicolumn{2}{|c|}{ Treatment of culture filtrate }} & \multicolumn{2}{|c|}{ Cytotoxic titer } \\
\hline & & FCS assay & NCS assay \\
\hline \multirow[t]{8}{*}{ Unheated } & Nondialyzed & 4 & 8 \\
\hline & $+\mathrm{FCS}^{\mathrm{a})}$ & 4 & 8 \\
\hline & $+\mathrm{NCS}$ & 4 & 8 \\
\hline & +NRS & 2 & 8 \\
\hline & Dialyzed ${ }^{\mathrm{b}}$ & 2 & $<2$ \\
\hline & $+\mathrm{FCS}$ & 2 & 2 \\
\hline & $+\mathrm{NCS}$ & 2 & $<2$ \\
\hline & +NRS & 2 & $<2$ \\
\hline \multirow[t]{8}{*}{ Heated ${ }^{c)}$} & Nondialyzed & $<2$ & 8 \\
\hline & $+\mathrm{FCS}$ & $<2$ & 8 \\
\hline & $+\mathrm{NCS}$ & 4 & 8 \\
\hline & +NRS & $<2$ & 8 \\
\hline & Dialyzed & $<2$ & $<2$ \\
\hline & $+\mathrm{FCS}$ & $<2$ & $<2$ \\
\hline & $+\mathrm{NCS}$ & $<2$ & $<2$ \\
\hline & $+N R S$ & $<2$ & $<2$ \\
\hline
\end{tabular}

a) $10 \%$ Serum was added to the culture filtrate.

b) Culture filtrate was dialyzed at $4^{\circ} \mathrm{C}$ for $24 \mathrm{hr}$.

c) Culture filtrate was heated at $100^{\circ} \mathrm{C}$ for $30 \mathrm{~min}$. 
Table 6. Effects of heating, dialysis, and addition of serum on cytotoxic activity in the SFC assay system

\begin{tabular}{llcccc}
\hline \multirow{2}{*}{ Treatment of culture filtrate } & \multicolumn{5}{c}{ Cytotoxic titer after addition of } \\
\cline { 2 - 6 } & None & FCS $^{\text {(4) }}$ & NCS $^{\text {a) }}$ & NRS $^{\text {a) }}$ \\
\hline \multirow{2}{*}{ Unheated } & Nondialyzed & 128 & $<2$ & 8 & $<2$ \\
& Dialyzed $^{\text {b) }}$ & 64 & $<2$ & $<2$ & $<2$ \\
\multirow{2}{*}{ Heated $^{(4)}$} & Nondialyzed & 16 & $<2$ & 8 & $<2$ \\
& Dialyzed & 4 & $<2$ & $<2$ & $<2$ \\
\hline
\end{tabular}

a) $10 \%$ Serum was added to the culture filtrate.

b) Culture filtrate was dialyzed at $4^{\circ} \mathrm{C}$ for $24 \mathrm{hr}$.

c) Culture filtrate was heated at $100^{\circ} \mathrm{C}$ for $30 \mathrm{~min}$.

\section{DISCUSSION}

Although we failed to reach a conclusion because the cytotoxins were not purified, some evidence suggested that at least three different types of cytotoxin were detected in the culture filtrate of $C$. jejuni by using three different culture media for $\mathrm{CHO}$ cells for detecting the cytotoxic activity. The first cytotoxin detected in the FCS assay system was heat-labile with an Mw estimated at 50-100 k. The second cytotoxin detected in the NCS assay was heatstable with an estimated $\mathrm{Mw}$ of $0.5-3.0 \mathrm{k}$. The third cytotoxin detected in SFC assay was most heat-labile and non-dialyzable but the $\mathrm{Mw}$ range could not be determined by ultrafiltration. Although the $\mathrm{pH}$ lability was similar among the assay systems, other properties were very different. The cytotoxic activity in FCS and NCS but not in SFC assay was abolished upon treatment with a reducing agent such as L-cysteine, sodium metabisulfite, and dithiothreitol. MEM and Brucella broth also contained Lcysteine and sodium metabisulfite at a concentration of 0.031 and $0.1 \mathrm{mg} / \mathrm{ml}$, respectively, but the cytotoxic activity was not inhibited at either concentration in these assay systems.

The possibility of different cytotoxic factors detected in the three assay systems was demonstrated by our previous data [29], i.e., the differences in the sensitivity to the tissue culture cells and in the cytotoxic activity with the bacterial culture conditions in the three assay systems. We demonstrated also that the cytotoxic activity was dependent on serum added to the tissue culture medium [29]. Further examinations were designed to determine the effect of serum added to the culture filtrate or SFC assay on the cytotoxic activity. Serum added to the filtrate did not affect the cytotoxic activity when $\mathrm{CHO}$ cells had already been cultured in MEM with FCS or NCS, whereas that in the SFC assay was completely depressed by FCS or NRS added. Interestingly, when NCS was added to the heated filtrate in which cytotoxic activity was no longer detected in FCS assay, the cytotoxic activity was restored, but it was abolished after dialysis (Table 5). It was considered that the restoration of the cytotoxicity in FCS assay may have been caused by activation by NCS added.

Furthermore, when the filtrate was dialyzed to remove the low Mw cytotoxin, the cytotoxic activity was detectable in the FCS assay but not in the NCS assay system. These results also indicate that the cytotoxin detected in FCS or NCS assay may have been activated by the specific serum. However, we failed to determine whether the cytotoxins detected in this study were proteins or some other substance since the cytotoxic activity was not inactivated or neutralized with any enzyme or did not cross-react with antibodies against reference toxins or bacteria-associated antigen. Although data were shown only for the $C$. jejuni strain BL 107, all of the characteristics mentioned above were obtained also with culture filtrates of strains HP5113, LCDC4483 and CCUG7755 reported previously [29].

A question has been raised whether the cytotoxins detected in this study are identical to those reported by other researchers. It is difficult to compare the characteristics of the cytotoxins since the procedures used for preparing and detecting the cytotoxins differ among laboratories. $C$. jejuni has been reported to produce heatlabile $[9,12,13,16,38]$ and/or heat-stable cytotoxin [14, 28]. The heat-labile cytotoxin was inactivated with trypsin and $\mathrm{Mw}$ was estimated at 30 to $100 \mathrm{k}[13,25,31]$. Although $\mathrm{Mw}$ of the heat-labile cytotoxin detected in this study was in the same range, the trypsin sensitivity did not agree with other reports. The cytotoxin detected in FCS assay may have been different from that detected with a bacterial culture medium supplemented with IsoVitale $\mathrm{X}$ or sodium metabisulfite $[4,16]$ because we failed to detect it under the same culture conditions [29].

The cytotoxin detected in NCS assay was heat-stable, had a low Mw and was inactivated with a reducing agent but not with trypsin. A few studies [14, 28] on heat-stable cytotoxins of $C$. jejuni have been performed, but there is no reports on cytotoxin with $\mathrm{Mw}$ of 0.5 to $3.0 \mathrm{k}$. Among the researchers $[9,11,25]$ who adopted the NCS assay system for $C$. jejuni cytotoxin detection, only Mahajan and Rodgers [25] reported that $\mathrm{Mw}$ was $68 \mathrm{k}$, but the others did not report the characteristics of the cytotoxins. Lam [23] did not demonstrate such properties as Mw or trypsin sensitivity of the heat-stable cytotoxin, either.

We have not been able to determine whether one or more components were included in the toxin detected in SFC assay since the $\mathrm{Mw}$ was not necessarily uniform in ultrafiltration. The cytotoxic activity was mostly heat-labile and completely abolished with FCS or NRS but not with IsoVitale X [29], reducing agents or by dialysis with 6 to 8 $\mathrm{k}$ cutoff membrane. These findings support the assumption that the heat-labile cytotoxin detected in the SFC assay is distinct from that detected in the FCS or NCS assay system. $\mathrm{Mw}$ of the heat-labile cytotoxin detected in SFC assay might be high. The heat-stable and low Mw cytotoxin detected in the NCS assay might also be detectable in SFC assay because the cytotoxic activity was not completely abolished with NCS. The fact that the cytotoxic activity was not detectable when NCS was added to the culture filtrate after dialysis also supports these findings. McCardell et al. [28] reported that heat-stable cytotoxin with $\mathrm{Mw} 70 \mathrm{k}$, was 
detected when the concentration of FCS in the tissue culture medium was reduced to $0.7 \%$, and that the cytotoxicity was inactivated with NRS. These characteristics resembled those of the cytotoxin detected in the SFC assay, but we failed to detect any cytotoxicity when 1\% FCS was added [29].

Other reports have been published concerning cytotoxic or cytolytic activities of $C$. jejuni, i.e, cytolethal distending toxin [17], hepatotoxin [18, 19], and hemolysin [14, 32]. However, we could not compare our data with those of these toxins since their purification and characterization have not been completed. Florin and Antillon [9] also pointed out that it was impossible to deduce from published reports how many cytotoxins had been detected. It is considered that such a confusing status is attributable to the presence of several different toxins, genetic regulation to express the cytotoxicity, or lack of a reliable assay system for studying cytotoxins of Campylobacter. It is important for solving the controversy as indicated by Ruiz-Palacios [33] that reference strains producing toxins and details of methods would become easily exchangable between researchers.

We reported that cytotoxic activity was detectable in NCS assay but not in the FCS assay when Vero cells were used, while it was detectable in both assay systems when $\mathrm{CHO}$ cells were used [29]. Such differences in sensitivity between tissue culture cells have also been reported by another researchers $[16,38]$. There are two possibilities concerning these differences. First, as mentioned by Florin and Antillon [9], two different cytotoxins, Vero-active and non-Veroactive, are produced. Second, this discrepancy may have been derived from the serum for tissue culture used by laboratories. We usually confirmed that the cytotoxic activity of the heat-inactivated culture filtrate was always negative in the FCS assay using different lots of FCS, because the activity was found to vary among FCS lots (unpublished data). We previously reported that the cytotoxic activity of $C$. jejuni was inactivated by addition of horse serum [29]. Horse serum used for detecting cytotoxin may affect the results of detecting $C$. jejuni toxin because horse serum was usually used for $\mathrm{Y}-1$ cell culture with FCS. It is important that lots of serum used for the cytotoxin detection are checked in future experiments. C. jejuni strains which produced both cytotoxin and cytotonic enterotoxin demonstrated that the culture filtrate was cytotoxic to HeLa and Vero cells, and enterotoxin in the same culture filtrate was detected by morphological changes, such as elongation of $\mathrm{CHO}$ cells or rounding of Y-1 cells $[4,16]$. However, it was reported that the cytotoxin of $C$. jejuni had cytolethal activity on CHO cells [11-13,25] and Y-1 cells [1]. These findings, together with our data, suggest that the cytotoxic activity was dependent on serum added to tissue culture medium and that the substance amplifying and/or inhibiting the cytotoxic activity may be present in serum. If the cytotoxins are related to pathogenesis, such factors on the host side as mediators amplifying the toxic activity may be important in causing illness. To clarify the role of these cytotoxins in pathogenesis, purification and further characterization are currently under way in our laboratories.

\section{REFERENCES}

1. Akhtar, S. Q. and Huq, F. 1989. Effect of Campylobacter jejuni extracts and culture supernatants on cell culture. $J$. Trop. Med. Hyg. 92: 80-85.

2. Belbouri, A. and Megraud, F. 1988. Enterotoxin-like activity produced by Campylobacter jejuni and Campylobacter coli isolated from patients and healthy controls in Algeria. FEMS Microbiol. Lett. 51: 25-28.

3. Blaser, M. J., Berkowitz, I. D., LaForce, F. M., Cravens, J., Reller, L. B., and Wang, W. I. 1979. Campylobacter enteritis clinical and epidemiological features. Ann. Intern. Med. 91: 179-185.

4. Bok, H. E., Greeff, A. S., and Crewe-Brown, H. H. 1991. Incidence of toxigenic Campylobacter strains in South Africa. J. Clin. Microbiol. 29: 1262-1264.

5. Butzler, J. P. and Skirrow, M. B. 1979. Campylobacter enteritis. Clin. Gastroenterol. 8: 737-765.

6. Collins, S., O'Loughlin, E., O'Rourke, J., Li, Z., Lee, A., and Howden, M. 1992. A cytotonic, cholera toxin-like protein produced by Campylobacter jejuni. Comp. Biochem. Physiol. 103B: 299-303.

7. Daikoku, T., Kawaguchi, M., Takama, K., and Suzuki, S. 1990. Partial purification and characterization of the enterotoxin produced by Campylobacter jejuni. Infect. Immun. 58: 2414-2419.

8. Everest, P. H., Goossens, H., Butzler, J.-P., Lloyd, D., Knutton, S., and Ketley, J. M. 1992. Differentiated Caco-2 cells as a model for enteric invasion by Campylobacter jejuni and $C$. coli. J. Med. Microbiol. 37: 319-325.

9. Florin, I. and Antillon, F. 1992. Production of enterotoxin and cytotoxin and Campylobacter jejuni strains isolated in Costa Rica. J. Med. Microbiol. 37: 22-29.

10. Goossens, H., Butzler, P.-J., and Takeda, Y. 1985. Demonstration of cholera-like enterotoxin production by Campylobacter jejuni. FEMS Microbiol. Lett. 29: 73-76.

11. Gooseens, H., Rummens, E., Cadranel, S., Butzler, J.-P., and Takeda, Y. 1985. Cytotoxic activity on Chinese hamster ovary cells in culture filtrates of Campylobacter jejuni/coli. Lancet 2: 511 .

12. Guerrant, R. L., Fang, G., Pennie, R. A., and Pearson, R. D. 1992. In vitro models for studying Campylobacter jejuni infections. pp. 160-167. In: Campylobacter jejuni (Nachamkin, I., Blaser, M. J., and Tompkins, L. S. eds.), American Society for Microbiology, Washington, D. C.

13. Guerrant, R. L., Wanke, C. A., Pennie, R. A., Barrett, L. J., Lima, A. A. M., and O'Brien, A. D. 1987. Production of a unique cytotoxin by Campylobacter jejuni. Infect. Immun. 55: 2526-2530.

14. Hossain, A., Stewart-Tull, D. E. S., and Freer, J. H. 1993. Heat-labile and heat-stable haemolysins of Campylobacter jejuni. FEMS Immun. Med. Microbiol. 6: 331-340.

15. Johnson, W. M. and Lior, H. 1985. Toxigenicity studies of Campylobacter species. p. 153. In: Campylobacter III (Pearson, A. D., Skirrow, M. B., Lior, H., and Rowe, B. eds.), Public Health Laboratory Service, London.

16. Johnson, W. M. and Lior, H. 1986. Cytotoxic and cytotonic factors produced by Campylobacter jejuni, Campylobacter coli and Campylobacter laridis. J. Clin. Microbiol. 24: 275281. 
17. Johnson, W. M. and Lior, H. 1988. A new heat-labile cytolethal distending toxn (CLDT) produced by Campylobacter spp. Microb. Pathog. 4: 115-126.

18. Kita, E., Nishikawa, F., Kamikaidou, N., Nakano, A., Katsui, N., and Kashiba, S. 1992. Mononuclear cell response in the liver of mice infected with hepatotoxigenic Campylobacter jejuni. J. Med. Microbiol. 37: 326-331.

19. Kita, E., Oku, D., Hamuro, A., Nishikawa, F., Emoto, M., Yagyu, Y., Katsui, N., and Kashiba, S. 1990. Hepatotoxic activity of Campylobacter jejuni.J. Med. Microbiol. 33: $171-$ 182.

20. Klipstein, F. A. and Engert, R. F. 1984. Properties of crude Campylobacter jejuni heat-labile enterotoxin. Infect. Immun. 45: 314-319.

21. Klipstein, F. A. and Engert, R. F. 1984. Purification of Campylobacter jejuni enterotoxin. Lancet 1: 1123-1124.

22. Klipstein, F. A. and Engert, R. F. 1985. Immunological relationship of the B subunits of Campylobacter jejuni and Escherichia coli heat-labile enterotoxins. Infect. Immun. 48: 629-633.

23. Lam, K. M. 1993. A cytotoxicity test for the detection of Campylobacter jejuni toxin. Vet. Microbiol. 35: 133-139.

24. Lior, H., Woodward, D. L., Edgar, J. A., Laroche, L. J., and Gill, P. 1982. Serotyping of Campylobacter jejuni by slide agglutination based on heat-labile antigenic factors. J. Clin. Microbiol. 15: 761-768.

25. Mahajan, S. and Rodgers, F. G. 1990. Isolation, characterization, and host-cell-binding properties of a cytotoxin from Campylobacter jejuni. J. Clin. Microbiol. 28: 1314-1320.

26. McCardell, B. A., Madden, J. M., and Lee, E. C. 1984. Production of cholera-like toxin by Campylobacter jejunilcoli. Lancet 1: 448-449.

27. McCardell, B. A., Madden, J. M., and Lee., E. C. 1984. Campylobacter jejuni and Campylobacter coli production of a cytotonic toxin immunologically similar to cholera toxin. $J$. Food Prot. 47: 943-949.

28. McCardell, B. A., Madden, J. M., and Stanfield, J. T. 1986.
Production of cytotoxins by Campylobacter. Lancet 1: 1031 .

29. Misawa, N., Ohnishi, T., Itoh, K., and Takahashi, E. 1994 Development of appropriate assay system for Campylobacter jejuni cytotoxin using tissue culture and the influence of culture conditions on cytotoxin production. J. Med. Microbiol. 41: 224-230.

30. Moore, M. A., Blaser, M. J., Perez-Perez, G. I., and O'Brien, A. D. 1988. Production of a Shiga-like cytotoxin by Campylobacter. Microb. Pathog. 4: 455-462.

31. Pang, T., Wong, P. Y., Puthucheary, S. D., Sihotang, K., and Chang, W. K. 1987. In-vitro and in-vivo studies of a cytotoxin from Campylobacter jejuni. J. Med. Microbiol. 23: 193-198.

32. Pickett, C. L., Auffenberg, T., Pesci, E. C., Sheen, V. L., and Jusuf, S. S. D. 1992. Iron acquisition and hemolysin production by Campylobacter jejuni. Infect. Immun. 60: 3872-3877.

33. Ruiz-Palacios, G. M. 1992. Pathogenesis of Campylobacter infection: in vitro models. pp. 158-159. In: Campylobacter jejuni (Nachamkin, I., Blaser, M. J., and Tompkins, L. D. eds.), American Society for Microbiology, Washington, D. C.

34. Ruiz-Palacios, G. M., Lopez-Vidal, Y., Torres, J., and Torres, N. I. 1985. Serum antibodies to heat-labile enterotoxin of Campylobacter jejuni. J. Infect. Dis. 152: 413-416.

35. Ruiz-Palacios, G. M., Torres, N. I., Torres, J., Escamilla, E., Ruiz-Palacios, B., Ruiz-Palacios, B. R., and Tamayo, J. 1983. Chorela-like enterotoxin produced by Campylobacter jejuni: characterization and clinical significance. Lancet 2: 250-252.

36. Skirrow, M. B. 1977. Campylobactr enteritis: a "new" disease. Br. Med.J. 2: 9-11.

37. Walker, R. I., Caldwell, M. B., Lee, E.C., Guerry, P., Trust, J., and Ruiz-Palacios, G. M. 1986. Pathophysiology of Campylobacter enteritis. Microbiol. Rev. 50: 81-94.

38. Yeen, W. P., Puthucheary, S. D., and Pang, T. 1983. Demonstration of a cytotoxin from Campylobacter jejuni. J. Clin. Microbiol. 36: 1237-1240. 